\title{
The use of the thoracic-abdominal rebalancing technique in a patient with acute viral bronchiolitis: an experimental report
}

\author{
Ana Paula Felix Arantes 1, * \\ ${ }^{1}$ Department of Physical Therapy, Municipal University Hospital, Rio Verde, GO, Brazil. \\ ${ }^{*}$ Corresponding author: Ana Paula Felix Arantes. Municipal University Hospital. Jeronimo Martins Street, s/n- \\ Parque Bandeirantes District. Zip Code: 75900-000 - Rio Verde, GO, Brazil. Phone: +55 (64) 9 9675-0094. E-mail: \\ ana_paula_arantes@hotmail.com
}

Research Ethics Committee Approval (if necessary): The authors stated that the patient's family approved the study by signing an informed consent form and the study followed the ethical guidelines established by the Declaration of Helsinki.

Received on: Sep 30, 2021. Accepted on: Oct 17, 2021. Available online: Oct 21, 2021.

\begin{abstract}
Acute Viral Bronchiolitis (AVB) commonly affects newborns and infants causing signs of mild to moderate respiratory distress, presenting in some cases, need of hospital care to these patients. Thus, despite the low evidence levels of indicating the use of conventional therapies while treating BVA, this article presents the effectiveness of the Thoracic-Abdominal Rebalancing (TAR) technique in a newborn diagnosed with BVA during his hospital stay. The ATR technique proved to be effective in improving signs of respiratory effort when used in an infant hospitalized for AVB.
\end{abstract}

Keywords: Physical Therapy Modalities; Viral Bronchiolitis; Pediatrics.

\section{Introduction}

Acute viral bronchiolitis (AVB) is a common lung infection in young individuals involving the lower respiratory tract and may present with signs of mild to moderate respiratory distress, the most common cause of which is respiratory syncytial virus
(RSV) [1]. AVB usually presents as a mild and self-limited infection in most children, which can be treated in an outpatient setting, but sometimes it can progress to respiratory failure concomitantly with hospitalization [2].

AVB is most common in children under 2 years of age. During the first

ISSN: 2763-583X. doi: 10.52600/2763-583X.bjcr.2021.1.4.70-78. This is an open acess article under the CC BY license by Creative Commons Attribution 4.0 International License. 
The use of the Thoracic-Abdominal Rebalancing technique in a patient with acute viral

year of life, the incidence has been reported to be about $11 \%$ to $15 \%$. Depending on the severity of the infection, there are at least 5 hospitalizations for every 1000 children under 2 years of age. Bronchiolitis is classically a more common seasonal disorder during autumn and winter, but sporadic cases can occur throughout the year [3].

AVB is usually treated with hydration and oxygen as no specific medication treats the infection, which can affect individuals of any age, but in general, the more severe symptoms tend to be common in babies, which can be associated with following risk factors: low birth weight (premature babies), age less than 5 months, low socioeconomic population, airway abnormalities, congenital immunodeficiency disorders, parental smoking, crowded living environment and chronic lung disease (bronchopulmonary dysplasia) [4].

The clinical features of AVB are mainly due to airway obstruction and decreased lung compliance. Once RSV is acquired, symptoms of an upper respiratory tract infection appear and include cough, fever and rhinorrhea and become symptoms of acute lower airway infection within 72 hours, during the acute stage, the baby may develop obstruction of the small airways and symptoms of respiratory distress with a variable level of severity according to each case [5].

The course of the disease can last from 7 to 10 days, and the child may be irritable and not eat. However, most babies improve within 14 to 21 days, as long as they are well hydrated and have undergone symptomatic treatment with a good prognosis. Most children recover without any adverse effects, but studies have shown that some patients with severe AVB may develop respiratory diseases such as asthma in the future [6].

Previous studies and national and international consensus on the subject agree that respiratory physiotherapy should not be routinely used in patients with AVB, as it can contribute to the increase in the child's stress levels [7-9]. Even with the existence of this consensus, in many Brazilian hospital institutions, medical prescriptions requesting respiratory physiotherapy for patients with AVB are still frequent [10-12].

The

Thoracic-Abdominal Rebalancing technique (TAR) is a physical therapy method that aims to improve lung function through the reorganization of respiratory muscle synergism, which was devised by the Brazilian physical therapist Mariângela Pinheiro de Lima in the early 1980s and has since been widespread and used as an alternative of physiotherapeutic treatment in patients with functional 
dysfunctions of the thoracoabdominal muscles [13].

It is considered an unconventional method of respiratory physiotherapy that differs from other physiotherapeutic techniques because it is based on the biomechanics of the respiratory system, with handling that does not generate loads on this system ${ }^{14}$. Recent studies have shown the effectiveness of its application in various respiratory and motor pathologies leading to the improvement of cardiorespiratory variables [15-20].

The performance of respiratory physiotherapy in the acute phase of patients affected by AVB is still controversial, so it was decided to carry out a study that would try to understand the effects of using an unusual physiotherapy technique on their cardiorespiratory variables.

The following study aims to report a case of a newborn diagnosed with AVB and submitted to the TAR physiotherapeutic technique during his hospital stay through the evaluation of his cardiorespiratory variables.

\section{Material and Methods}

This is a descriptive study, of the experience report type, described according to the methodology CARE Case Reports Guidelines [21]. The same was developed in the context of physical therapy monitoring during the period of hospitalization in a public hospital in a municipality in the southwest region of the state of Goiás of an infant diagnosed with AVB.

A 13-day-old male newborn participated in this study. He was included because he had a clinical diagnosis of AVB and had no comorbidities or pre- or neonatal history.

Parents were invited to participate in the study and signed an informed consent form. As soon as the authorization form of the person responsible for the place where the study was carried out was signed, data collection was carried out, which was carried out in one step, through the analysis of the research participant's medical records.

For data collection, a structured form designed and applied by the researcher was used, consisting of two sections: 1) data related to hospital admission and 2) data related to physical therapy treatment with the TAR technique: heart rate, respiratory rate and saturation oxygen peripheral, through the multiparametric monitor of the brand Dixtal Biomedica, model DX2021 and the degree of respiratory discomfort through the Bulletin of Silverman-Andersen (BSA) [22].

The BSA consists of a score to assess the degree of respiratory distress and pulmonary impairment through 
The use of the Thoracic-Abdominal Rebalancing technique in a patient with acute viral

scores from 0 to 2 for each of the five parameters evaluated (upper intercostal retraction; lower intercostal retraction; xiphoid retraction; nasal wing beat and expiratory moaning). The sum of scores below five indicates mild respiratory distress, and when it is equal to 10 , it corresponds to the maximum degree of dyspnea [22].

Before each of the six physical therapy sessions to which the subject has been subjected, she had her naked chest was positioned supine with head elevated to 45 degrees and coupled to multiparameter monitoring electrodes.

Only then the newborn was assisted for 20 minutes by a physiotherapist trained in the TAR technique. The sessions consisted of the following handlings of the technique: posterior muscle chain stretching, thoracoabdominal support and lower abdominal support, which were performed for 5-6 minutes each (Figure 1).

The therapeutic approach carried out remained unchanged throughout the treatment. Before and after each TAR session, respiratory rate, heart rate and peripheral oxygen saturation, and the degree of respiratory distress were evaluated and recorded.

The collected data were analyzed using descriptive statistics using the Microsoft Excel program and using the Student's $\mathrm{t}$ test and discussed among themselves, based on relevant literature. The statistical measures used were absolute and relative frequency, determination of the median mean and standard deviation with a significance level of $5 \% \quad(p<0.05)$ and a $95 \%$ confidence interval.

\section{Results}

The child had persistent dry cough at home and was taken to a basic health unit, where he was treated for three days with antibiotic therapy but developed respiratory failure and was transferred to the University Municipal Hospital emergency room.

In this unit, the newborn was finally diagnosed with AVB, initially kept in the emergency room, where he remained for two days in the emergency room until his respiratory condition improved. During this period that he remained in the emergency room, he was under oxygen therapy by Hood at $40 \% \mathrm{FiO}_{2}$, other nursing care, prescription of daily respiratory physiotherapy, antibiotic therapy, he was kept on a free diet (maternal breast), antipyretic medication if necessary, and inhaled and intravenous bronchodilators.

In all six respiratory physiotherapy sessions to which the minor was submitted were performed only with the TAR technique. Before the first session, still in the emergency 
room, the infant presented tachypnea, signs of respiratory effort, intercostal and substernal in drawls. In the sixth session, the patient already had no respiratory effort and on the same day he was discharged from the hospital.
After each one of the physiotherapy sessions with the TAR technique, there was an improvement in all four evaluated parameters, except for the heart rate (Table 1).
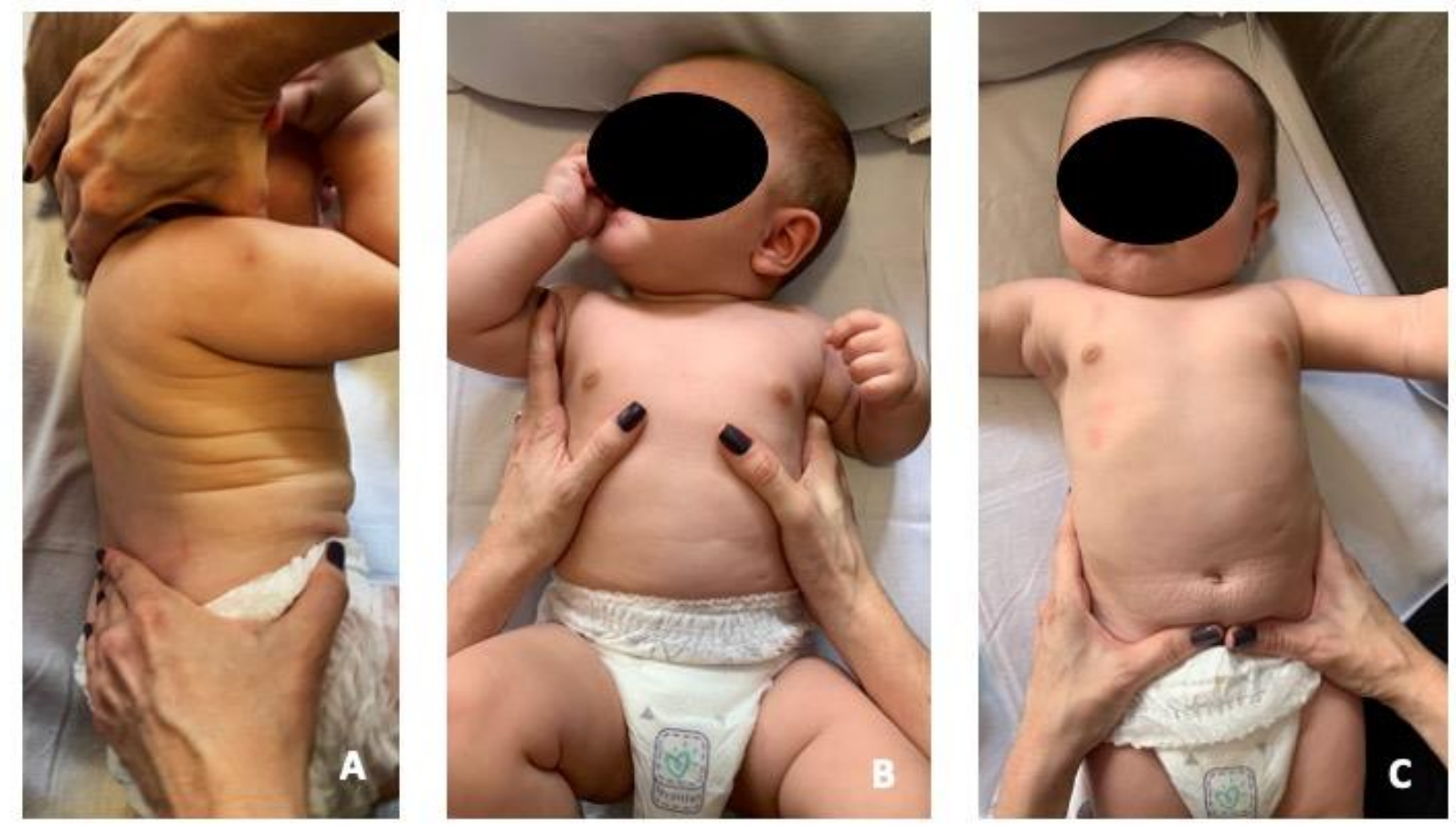

Figure 1. Thoracic-Abdominal Rebalancing technique handlings used during the physiotherapy sessions. A. Posterior muscle chain stretching. B. Thoracoabdominal support. C. Lower abdominal support.

Table 1. Descriptive analysis of evaluated parameters on each Physical Therapy sessions before and after using the Thoracic-Abdominal Rebalancing Technique in a newborn diagnosed with Acute Viral Bronchiolitis.

\begin{tabular}{lcc}
\hline \multicolumn{1}{c}{ Evaluated parameters } & Average \pm Standard Deviation & $\mathbf{p}^{*}$ \\
\hline Heart Rate & $140,83 \pm 21,34$ & 0,064 \\
$\quad$ Initial & $140,83 \pm 13,38$ & \\
$\quad$ Final & & \\
Respiratory Rate & $46,50 \pm 9,39$ & 0,005 \\
$\quad$ Initial & $37,67 \pm 7,80$ & \\
$\quad$ Final & & 0,000 \\
Oxigen Saturation & $90,50 \pm 6,29$ & \\
$\quad$ Initial & & \\
& & \\
\hline \hline
\end{tabular}


Final

\section{Respiratory Distress}

Initial

Final
$95,33+5,47$

$2,83 \pm 2,61$

0,000

${ }^{*} \mathrm{p}$ values determined by Student $\mathrm{t}$ test.

\section{Discussion and Conclusion}

AVB causes an increase in secretions in the airways of the affected patient, causing obstruction, alveolar collapse, pulmonary hyperinflation, and clinical manifestations such as tachypnea and signs of respiratory distress [1]. Changes in pulmonary auscultation are also observed, which can present adventitious noises such as wheezing and crackling rales due to the inflammatory process [23].

National and international consensus agree that respiratory physiotherapy should not be routinely used in AVB patients, as it can contribute to the increase in the child's stress levels [1,7]. Even with the existence of this consensus, in many Brazilian hospital institutions, medical prescriptions requesting respiratory physiotherapy for patients with acute bronchiolitis are still frequent [11].

A study with infants with AVB undergoing conventional physiotherapy showed that there was no overall benefit in improving cardiorespiratory parameters and that the possibility of indicating respiratory physiotherapy could be considered when the pathology is in its subacute period, that is, with more presence of secretions [24].

The patient remained in the unit for a total of six days until he was discharged from the hospital with his clinical respiratory condition resolved, eupneic, spontaneously breathing room air, with absence of drafts or alterations in pulmonary auscultation. He was discharged from the hospital with a medical prescription to continue the treatment with oral antibiotic therapy for five days and instructions to return to an emergency room in case of worsening of symptoms, which means the average of length of stay as most of the patients his age in the similar conditions [25].

The hallmark of treatment for children with bronchiolitis is symptomatic care. All infants and children diagnosed with bronchiolitis should be carefully evaluated for adequate hydration, respiratory distress, and the presence of hypoxia. Bronchiolitis is a common manifestation for physicians and significantly increases the cost of healthcare. To decrease morbidity, diagnosis and 
treatment of bronchiolitis is best done with an interprofessional team that includes the emergency department physician, nurse, pediatrician, primary caregiver, and infectious disease consultant.

The AVB diagnosis is clinical and, in most cases, its treatment is considered supportive. When the baby is ill, the caregiver should be instructed when to take the baby to the hospital/doctor and should not seek alternative remedies. Monitoring the baby is necessary to ensure that improvement is taking place. Only through open communication with the interprofessional team can results be improved and complications reduced. When the disorder is recognized and treated, the prognosis is excellent. Most children recover without any adverse effects.

In the present study, the TAR method showed a significant improvement in respiratory rate, oxygen saturation and signs of respiratory effort when used in an infant hospitalized for AVB in a short-term period. However, due to the scarcity of publications proving the benefit of conventional respiratory physiotherapy or the TAR technique in this type of patient, it is suggested that more studies be carried out on the subject so that its effectiveness can be evidenced.

\section{References}

[1] SBP. Sociedade Brasileira De Pediatria. 2017. Diretrizes para o manejo da infecção causada pelo vírus sincicial respiratório (VSR).

[2] Justice NA, Le JK. Bronchiolitis. Em: StatPearls [Internet]. Treasure Island (FL): StatPearls Publishing; 2021 [citado 29 de Setembro de 2021].

[3] Khemani RG, Smith L, LopezFernandez YM, Kwok J, Morzov R, Klein MJ, Yehya N, Willson D, Kneyber MCJ, Lillie J, Fernandez A, Newth CJL, Jouvet $\mathrm{P}$, Thomas NJ; Pediatric Acute Respiratory Distress syndrome Incidence and Epidemiology (PARDIE) Investigators; Pediatric Acute Lung Injury and Sepsis Investigators (PALISI) Network. Paediatric acute respiratory distress syndrome incidence and epidemiology (PARDIE): an international, observational study. Lancet Respir Med. 2019 Feb;7(2):115128. doi: 10.1016/S2213-2600(18)30344-8.

[4] Ghazaly $\mathrm{MMH}, \mathrm{Abu}$ Faddan $\mathrm{NH}$, Raafat DM, Mohammed NA, Nadel S. Acute viral bronchiolitis as a cause of pediatric acute respiratory distress syndrome. Eur J Pediatr. 2021;180(4):1229-34.

[5] Wilder JL, Parsons CR, Growdon AS, Toomey SL, Mansbach JM. Pediatric hospitalizations during the covid-19 
pandemic. Pediatrics. Dezembro de 2020;146(6):e2020005983.

[6] Garcia-Garcia ML, GonzalezCarrasco E, Bracamonte T, Molinero M, Pozo F, Casas I, et al. Impact of prematurity and severe viral bronchiolitis on asthma development at 6-9 years. J Asthma Allergy. 2020;13:343-53.

[7] Ralston SL, Lieberthal AS, Meissner HC, Alverson BK, Baley JE, Gadomski $\mathrm{AM}$, et al. Clinical practice guideline: the diagnosis, management, and prevention of bronchiolitis. Pediatrics. 2014;134(5):e1474-502.

[8] Gomes GR, Donadio MVF. Effects of the use of respiratory physiotherapy in children admitted with acute viral bronchiolitis. Arch Pediatr. 2018;25(6):394-8.

[9] Schaller A, Galloway CS. Bronchiolitis in infants and children. S D Med. 2017;70(6):274-7.

[10] Kyler KE, McCulloh RJ. Current concepts in the evaluation and management of bronchiolitis. Infect Dis Clin North Am. 2018;32(1):35-45.

[11] Luisi F. O papel da fisioterapia respiratória na bronquiolite viral aguda. Sci med. 2008;18(1):39-44.

[12] Postiaux G, Zwaenepoel B, Louis J. Chest physical therapy in acute viral bronchiolitis: an updated review. Respir Care. 2013;58(9):1541-5.
[13] Lima M. Tórax enfisematoso tratamento fisioterápico. 1986;(9):27387.

[14] Lima MP. Bases do método reequilíbrio toraco-abdominal. Em: O $\mathrm{ABC}$ da Fisioterapia Respiratória. 2.a ed. São Paulo: Manole; 2012.

[15] Melluzzi MD, Farias AO de, Ruhoff GM, Villa LSC, Souza JS de, Nishida FS. A importância do fisioterapeuta no tratamento da displasia broncopulmonar / the importance of the physiotherapist in the treatment of broncopulmonary dysplasia. BJD. 2020;6(12):100853-63.

[16] Minagawa JS, Theodoro EM, Fernandes C, Ferreira CLBC, Hara CCG, Boschi SR da S, et al. Avaliação da efetividade do enfaixamento abdominal em crianças acometidas pela síndrome do lactente chiador. Revista Científica UMC. 2019;4(2):1-14.

[17] Oliveira NLMA, Santos CLR, Barreto LCLS, Albiero FM, Dantas LRP. Efeito do método reequilíbrio toracoabdominal em paciente com deficiência sulfito oxidase. Journal of Health Connections. 2017;1(1):19-32.

[18] Roussenq KR, Scalco JC, Rosa GJ da, Honório GJ da S, Schivinski CIS. Reequilíbrio tóraco-abdominal em recém-nascidos prematuros: efeitos em parâmetros cardiorrespiratórios, no comportamento, na dor e no 
desconforto respiratório. Acta Fisiátr. 2013;20(3):118-23.

[19] Santos RPB dos, Lourenço A, Santos LF dos, Neves AIA, Alencar CP de, Pinheiro YT. Efeitos da fisioterapia respiratória em bebês de risco sob cuidados especiais. Arch Health Invest. 2019;8(3).

[20] Tassinari CCDR, Koop L, Nunes SF, Antunes V da P. Influência do Método Reequilíbrio Tóraco-Abdminal em recém nascidos pré-termos pós Síndrome do Desconforto Respiratório internados na Unidade de Terapia Intensiva Neonatal - Estudo de casos. Revista Inspirar movimento \& saúde. 2012;4(4):38-41.

[21] Gagnier JJ, Kienle G, Altman DG, Moher D, Sox H, Riley D. The care guidelines: consensus-based clinical case reporting guideline development. Glob Adv Health Med. 2013;2(5):38-43.

[22] Silverman WA, Andersen DH. A controlled clinical trial of effects of water mist on obstructive respiratory signs, death rate and necropsy findings among premature infants. Pediatrics. 1956;17(1):1-10.

[23] Carvalho WB de, Johnston C, Fonseca MC. Bronquiolite aguda, uma revisão atualizada. Rev Assoc Med Bras. 2007;53(2):182-8.

[24] Pupin MK, Riccetto AGL, Ribeiro JD, Baracat ECE. Comparação dos efeitos de duas técnicas fisioterapêuticas respiratórias em parâmetros cardiorrespiratórios de lactentes com bronquiolite viral aguda. J bras pneumol. 2009;35(9):860-7.

[25] Steidl EM dos S. Influência do método reequilíbrio tóraco-abdominal em recém-nascidos pré-termos póssíndrome do desconforto respiratório. Rev. Cont. Saúde. 2013;11(21):43.

Conflict of interest: The author declares no conflicts of interest.

Acknowledgements: To the health care team involved in this case, the patient's family and also to the general director and the Physical Therapy Team of the University Municipal Hospital of the city of Rio Verde, Goiás, Brazil.

Funding: None.

How to cite this article: Arantes APF. The use of the thoracic-abdominal rebalancing technique in a patient with acute viral broncholitis: an experimental report. Brazilian Journal of Case Reports. 2021 Oct-Dec;01(4):70-78. 